\title{
Studies on the Epidemiology of Escherichia coli Infections. V. Factors Influencing Acquisition of Specific Serologic Groups *
}

\author{
Richard H. Winterbauer, $†$ Marvin Turck, $\$$ and Robert G. Petersdorf \\ (From the Department of Medicine, University of Washington School of Medicine, and \\ King County Hospital, Seattle, Wash.)
}

\begin{abstract}
Summary. Stool carrier rates of Escherichia coli serogroups 4, 6, and 75 were determined on admission and discharge for 190 patients. Persons who were in the hospital 3 weeks or longer had an intestinal carrier rate of $46 \%$ compared to a rate of $28 \%$ in individuals who had no recent hospital contact. Treatment with broad spectrum antibiotics increased the susceptibility for acquisition of certain specific serologic groups. This was apparently not related to replacement of sensitive $E$. coli by drug-resistant forms. Studies were made to determine the environmental source for colonization of hospitalized patients and the risk of urinary infection in stool carriers of these strains. A survey of inanimate objects of medical and urological wards demonstrated infrequent isolation of 04,06 , and 075 , indicating that extraintestinal foci were an unlikely source for hospital-acquired $E$. coli. Hemagglutination titers with determination of group-specific $O$ antibody failed to demonstrate any deficiency in hospitalized patients who became colonized with certain coliforms. Similarly, no significant deficit in group-specific serum antibody was found in patients who were community carriers of $E$. coli 04,06 , or 075 . Despite a high rate of acquisition of $E$. coli serogroups 4,6 , and 75 in the stools of hospitalized patients, only those patients undergoing urinary tract manipulation developed bacteriuria.
\end{abstract}

\section{Introduction}

Studies of the epidemiology of nonenteric illness caused by $E$. coli have shown clearly that the majority of these infections has been caused by $E$. coli in a few specific serologic groups, 04, 06, and 075 (1-3). Many of the infections involved the urinary tract and were acquired in the hospital.

* Submitted for publication April 25, 1966; accepted September 15, 1966.

This work was supported in part by training grant AI-146-06 and grant AI-06311-02 from the National Institutes of Health, U. S. Public Health Service. Presented in part at the Fifth Interscience Conference on Antimicrobial Agents and Chemotherapy, October 17, 1965.

† Epidemic Intelligence Service Officer, Communicable Disease Center, U. S. Public Health Service, assigned to the University of Washington.

$\ddagger$ Address requests for reprints to Dr. Marvin Turck, King County Hospital, Seattle, Wash. 98104.
Because $E$. coli is the predominant component of the fecal flora, it seemed reasonable to investigate the serologic character of the coliform population in the stool of hospitalized and nonhospitalized individuals. These studies demonstrated increased intestinal colonization by $E$. coli serogroups 04,06 , and 075 during and after hospitalization (4). The tendency to become colonized with strains in these O groups was directly related to the duration of hospitalization, and patients who were in the hospital 3 weeks or longer had an intestinal carrier rate of $60 \%$ compared to a rate of only $15 \%$ in individuals who had had no recent hospital contact. More importantly, patients subjected to prostatectomy who were fecal carriers of $E$. coli 04,06 , and 075 had a higher risk of developing bacteriuria with these strains than patients who carried other serologic groups in the stool. Recently, it has been shown that 29 of 53 urinary tract infections ac- 
quired outside the hospital were also due to $E$. coli 04,06 , and 075 and that these strains were present in the stools of $86 \%$ of patients with these infections (5). In contrast, the stool carrier rate in uninfected controls outside the hospital was only $28.3 \%$.

The precise reasons for the increased prevalence of these strains in the stools of hospitalized patients and their incidence as pathogens both in the hospital and in the community remain unknown. The studies to be described are aimed at clarifying the epidemiology of the infections by delineating hospital reservoirs of these strains, assessing the influence of antibiotic therapy on the acquisition of specific serologic groups of $E$. coli, determining the factors bearing on the development of bacteriuria, and evaluating the significance of the host's antibody in preventing colonization by $E$. coli 04,06 , and 075 .

\section{Methods}

Population surveyed. Two groups of individuals were studied. The first population consisted of 425 patients admitted to the medical wards of the King County Hospital between December 1, 1964, and April 26, 1965. These patients were selected because they had not been in contact with a hospital for at least 1 year before admission. Fifty-five per cent were male, the average age of the entire group was 62.4 years, and more than a third were older than 70 . Within 24 hours after admission, a rectal swab, clean-voided urine for culture, and a blood sample for determination of $\mathrm{O}$ antibody titer were obtained from each patient. At the time of discharge from the hospital, a second rectal swab and clean-voided urine sample were collected. Patients were excluded from this study if hospitalization was shorter than 1 week, or if follow-up cultures could not be obtained because of death or transfer to a nonparticipating service. In all, paired rectal swabs were adequate for study in 190 patients and admission and discharge urine cultures were obtained from 226 patients. At the time of discharge from the hospital, the patients' charts were carefully reviewed with particular emphasis on the past history of urinary tract infection or previously documented bacteriuria, and antibiotic therapy, genitourinary manipulation, and signs and symptoms of acute urinary tract infection during the present admission.

The second group consisted of 52 hospital personnel who worked daily on the medical wards during the period of surveillance. Rectal swabs were obtained from each individual in this group during the period of study.

Bacteriology. Rectal swabs were immediately placed in trypticase soy broth, refrigerated at $4^{\circ} \mathrm{C}$, and 1 to 6 hours later streaked directly onto $\mathrm{McC}$ Conkey agar plates. After a 24 -hour period of incubation at $37^{\circ} \mathrm{C}$, ten lactose- fermenting $E$. coli were picked for serologic grouping according to methods described previously (1). This number of colonies gives a satisfactory yield for epidemiologic purposes as delineated by Vosti, Monto, and Rantz (6). In their study, $80 \%$ of the total number of $O$ groups in a stool specimen was discovered by examination of the first five colonies. Stool carrier rates of $E$. coli 04, 06, and 075 were based on the occurrence of a strain in a patient, regardless of the number of colonies present. In the survey of inanimate objects and in patients with bacteriuria, gram-negative organisms other than $E$. coli also were identified. The scheme in use in this laboratory for identification of these organisms has been described previously (4). The number of organisms in all urine cultures was quantitated by serial dilution and $10^{5}$ bacteria per $\mathrm{ml}$ was defined as connoting significant bacteriuria. Antimicrobial sensitivity tests were performed on selected strains of $E$. coli. The single disc technique was employed (7).

Hemagglutinating $O$ antibody titers. Titers of hemagglutinating antibody to $E$. coli 04,06 , and 075 were determined by a modification of the method of Neter and co-workers (8). The antigen was prepared by inoculating stock cultures of $E$. coli 04,06 , and 075 into trypticase soy agar slants and incubating the culture overnight at $37^{\circ}$ C. The organisms were then washed from the slant with phosphate-buffered saline (PBS) and then diluted to a suspension of $10^{\circ}$ bacteria per $\mathrm{ml}$ with a McFarland tube. The suspension was heated at $100^{\circ} \mathrm{C}$ for $2 \frac{1}{2}$ hours and then centrifuged at $14,000 \mathrm{rpm}$ for 30 minutes (tip gravity, $23,500 \mathrm{~g})$. The supernatant containing the antigen was decanted and suspended in $95 \%$ ethanol to make a final dilution of $10 \%$ ethanol. Human $\mathrm{O}$ erythrocytes were washed three times with $\mathrm{PBS}$ and then diluted in a ratio of $0.2 \mathrm{ml}$ packed red blood cells to $6.0 \mathrm{ml}$ PBS. The erythrocyte solution was diluted with an equal volume of prepared antigen. The antigen-erythrocyte mixture was incubated at $37^{\circ} \mathrm{C}$ for 1 hour, and the sensitized cells were washed with PBS. The solution was centrifuged, and the packed, sensitized cells were then suspended in PBS to give a final concentration of $2.5 \%$ by volume. Four drops of the patient's serum was mixed with PBS to provide dilutions ranging from $1: 16$ to $1: 4,192$. Four drops of each dilution was then added to an equal volume of the sensitized red cell suspension and incubated at $37^{\circ} \mathrm{C}$ for 2 hours and then at room temperature overnight. The tubes were examined for agglutination, and the highest dilution of serum that produced macroscopic clumping was recorded.

Bacteriologic survey of inanimate objects in the hospital environment. A total of 519 cultures was obtained from three separate hospital wards, and the cultures were processed for the isolation and identification of $E$. coli 04,06 , and 075 . In addition, all aerobic gram-negative bacilli were identified in 312 of these cultures to provide data on the relative prevalence of gram-negative pathogens in the hospital environment. A bacteriologic survey of the urological service was included because of the previously documented high incidence of hospitalacquired urinary tract infections (4). 
TABLE I

Relationship of duration of hospital stay to stool carrier rate of E. coli 04, 06, and 075

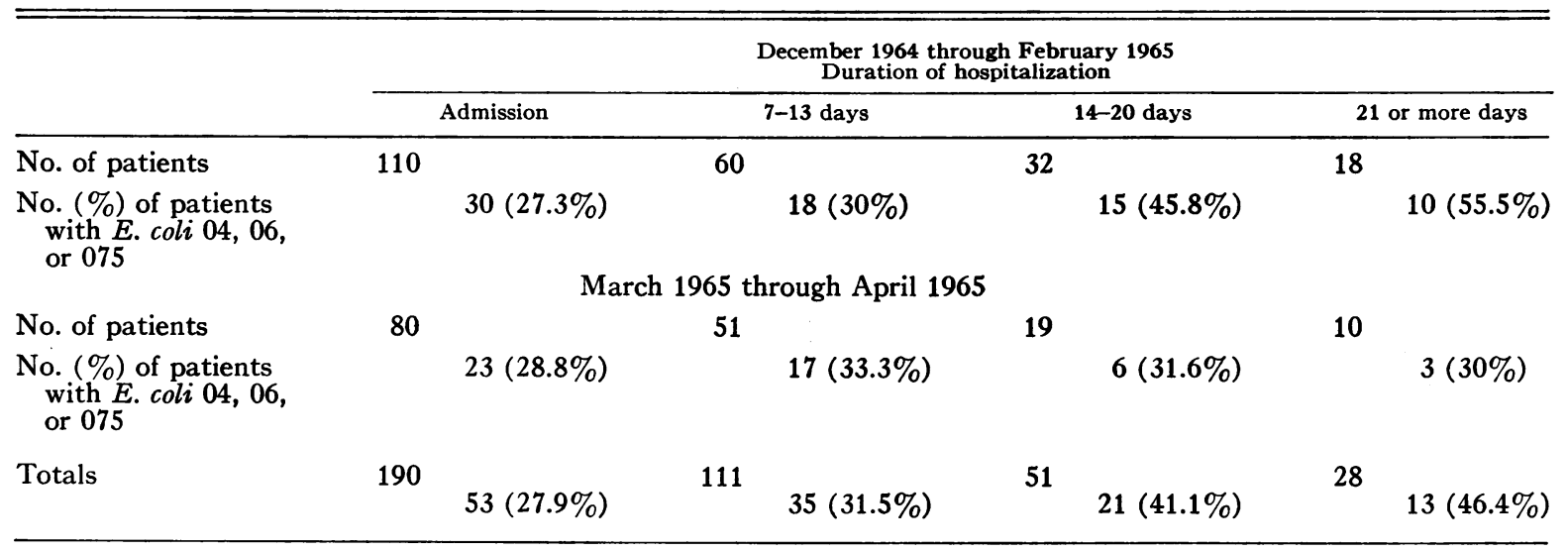

Sterile cotton swabs were used to culture a variety of inanimate objects in the hospital environment. All swabs were moistened in broth and were then streaked across floors, chairs, bedsheets, sinks, urinals, and so on. The swabs were placed in sterile tubes of trypticase soy broth for 1 hour, and the cotton tip was then streaked directly onto $\mathrm{McC}$ Conkey plates.

An additional $104 \mathrm{McC}$ Conkey plates were distributed in 35 rooms on the medical service and were exposed to the air for 2, 6, or 24 hours. All gram-negative isolates collected on these plates were identified.

\section{Results}

Stool carrier rates of $E$. coli 04, 06, and 075 . The fecal flora at the beginning and end of hospitalization was studied in 190 patients. None of these had been in contact with the hospital for at least 1 year before admission, and all were hospitalized for at least 1 week. On admission, 53 of the $190(27.9 \%)$ were intestinal carriers of $E$. coli 04,06 , or 075 (Table I). Intestinal colonization by serogroups 4,6 , and 75 increased with duration of hospital stay during the initial 3 months of the survey, and $55.5 \%$ of patients hospitalized for more than 3 weeks became intestinal carriers of these strains $(p<0.002)$. However, in the early spring months of March and April, the trend for increased colonization with these $O$ groups was no longer apparent, and the carrier rate upon admission to or discharge from the hospital did not vary appreciably from $30 \%$. The reason for this seasonal difference is not apparent, and the problem is under continued investigation.

In all, 33 of 137 patients who had not harbored E. coli 04,06 , or 075 in their stool on admission acquired these serogroups in the hospital. Twenty- four of these 33 patients were hospitalized in December, January, or February. The acquisition of O groups 4, 6, and 75 was not related to the patient's age, sex, specific disease, or degree of debility, but it did correlate with administration of antimicrobial agents (vide infra).

Influence of antibiotic therapy on colonization by $E$. coli 04, 06, and 075. Accurate information about use of antibiotics during the current admission was available for 171 of the 190 patients studied. The influence of antibiotic therapy on the fecal carrier rate with new serogroups of $E$. coli is summarized in Table II. Only $13.2 \%$ of patients not treated with antibiotics were colonized by 04,06 , or 075 , whereas $37.2 \%$ of patients receiving broad spectrum or multiple drug therapy acquired these strains $(p<0.002)$. The acquisition of new serogroups of $E$. coli other than 04,06 , or 075 was not related to the use of antibiotics, and a change of the coliform flora occurred in $21.7 \%$ of the untreated patients and $22.8 \%$ of those treated with broad spectrum antimicrobials. $\mathrm{Pa}$ tients receiving antibiotics directed primarily at gram-positive organisms, such as penicillin $G$ or erythromycin, also did not acquire new strains with greater frequency than did untreated controls. In all, $60 \%$ of patients treated with broad spectrum antibiotics acquired new serogroups of $E$. coli, whereas a change in flora was noted in only $35 \%$ of the group who had not received antimicrobials.

The average hospital stay of the 65 patients treated with any antibiotics was 15.3 days and did not differ significantly from the 12.7-day duration of hospitalization of patients who remained 
TABLE II

Relationship of antimicrobials to hospital acquisition of new E. coli serogroups

\begin{tabular}{ccccc}
\hline \hline $\begin{array}{c}\text { Type of antibiotic } \\
\text { therapy }\end{array}$ & $\begin{array}{c}\text { No. of } \\
\text { patients }\end{array}$ & $\begin{array}{c}\text { No. (\%) that } \\
\text { acquired } E \text {. coli } \\
04,06,075\end{array}$ & $\begin{array}{c}\text { No. (\%) that } \\
\text { acquired } E \text {. coli } \\
\text { of other } \\
\text { serogroups }\end{array}$ & $\begin{array}{c}\text { No. (\%) that } \\
\text { did not acquire } \\
\text { any new } E \text {. coli }\end{array}$ \\
\hline $\begin{array}{c}\text { No antibiotics } \\
\text { Antibiotics with } \\
\text { gram-positive } \\
\text { spectrum }\end{array}$ & 106 & $14(13.2 \%)$ & $23(21.7 \%)$ & $69(65.1 \%)$ \\
$\begin{array}{c}\text { Broad spectrum } \\
\text { or multiple drug } \\
\text { therapy }\end{array}$ & 30 & $6(20 \%)$ & $4(13.3 \%)$ & $20(66.7 \%)$ \\
Totals & 35 & $13(37.2 \%)$ & $8(22.8 \%)$ & $14(40.0 \%)$ \\
\hline
\end{tabular}

untreated. However, the hospital stay of the 13 patients who converted to stool carriage with $E$. coli 04,06 , or 075 and who received broad spectrum antibiotics was 22 days, a duration significantly greater than the 13.8 days found in $20 \mathrm{pa}$ tients who acquired these strains but who had not been treated with broad spectrum antimicrobials $(\mathrm{p}<0.02)$. The results suggest that acquisition of $E$. coli 04,06 , or 075 was secondary to the use of broad spectrum antibiotics rather than prolonged hospitalization per se.

A tendency for patients receiving broad spectrum antibiotics to acquire $E$. coli of serogroups 04,06 , and 075 raised the question whether these patients were acquiring resistant strains. Table III shows the results of antimicrobial sensitivity tests performed on 53 strains of $E$. coli serogroups 04,06 , and 075 isolated from the stools of patients before hospital contact, 33 strains of 04,06 , and 075 isolated from the stools of patients after prolonged hospitalization, and 55 strains of $E$. coli serogroups other than 04,06 , or 075 cultured from in-

TABLE III

Antimicrobial sensitivity of intestinal $E$. coli in relation to serogroup and source of acquisition

\begin{tabular}{lccc}
\hline \hline & & & $\begin{array}{c}\text { 55 strains, } \\
\text { community } \\
\text { other }\end{array}$ \\
& $\begin{array}{c}53 \text { strains, } \\
\text { community }\end{array}$ & $\begin{array}{c}\text { 33 strains, } \\
\text { hospital } \\
\text { [. 06, 07, }\end{array}$ & $\begin{array}{c}\text { 04, 06, 075 } \\
\text { serogroups }\end{array}$ \\
\hline & $\begin{array}{c}\text { \% sensi- } \\
\text { tive }\end{array}$ & $\begin{array}{c}\text { \% sensi- } \\
\text { tive }\end{array}$ & $\begin{array}{c}\text { \% sensi- } \\
\text { tive }\end{array}$ \\
Kanamycin & 87 & 100 & 100 \\
Polymyxin B & 98 & 100 & 100 \\
Chloramphenicol & 94 & 97 & 100 \\
Ampicillin & 94 & 94 & 96 \\
Streptomycin & 78 & 88 & 93 \\
Tetracycline & 87 & 85 & 78 \\
Sulfisoxazole & 85 & 85 & 89 \\
Cephalothin & 76 & 81 & 89 \\
\hline
\end{tabular}

dividuals outside the hospital. There was no significant difference in the antibiotic susceptibility patterns of these organisms; the mechanism whereby antibiotics promote intestinal colonization with 04,06 , and 075 is apparently not related to eradication of sensitive $E$. coli and their replacement by drug-resistant forms.

Hospital reservoirs of E. coli 04, 06, and 075. Investigations to delineate the hospital reservoirs of $\mathrm{O}$ groups 4, 6, and 75 were performed in December 1964 and January 1965, when the rate of intestinal colonization of these strains in hospitalized patients was high. The results of the survey are listed in Table IV. Klebsiella-Aerobacter, intermediate coliforms, Herellea, and $E$. coli other than 04,06 , and 075 were the four most common organisms isolated from the environment. Cultures from the urological service showed consistently fewer isolates and more sterile plates than were found on either of the two medical services. E. coli 04,06 , and 075 were isolated on only 18 occasions from 519 cultures. Previous studies performed on this urological ward indicated that $27 \%$ of all urinary tract infections acquired in the hospital were due to $E$. coli 04,06 , or 075 (4). Thus, despite their predominance as urinary pathogens, these strains accounted for only $5.7 \%$ of the total gram-negative flora isolated from inanimate objects on the urological service. These included floors, walls, sheets, thermometers, bed rails, urinals, catheters, water pitchers and glasses, chair seats, toilet and commode seats, sinks, wastebaskets, bathtubs, and table tops. There was no localization of gram-negative bacteria within certain rooms or on specific objects.

In addition to the sampling of inanimate objects, $104 \mathrm{McC}$ Conkey plates were exposed to the air for 
TABLE IV

Frequency of isolation of gram-negative organisms from inanimate objects

\begin{tabular}{|c|c|c|c|}
\hline Organism & $\begin{array}{l}\text { North medical ward } \\
(101 \text { cultures) } \\
\text { No. }(\%) \text { positive }\end{array}$ & $\begin{array}{l}\text { South medical ward } \\
(105 \text { cultures) } \\
\text { No. (\%) positive }\end{array}$ & $\begin{array}{l}\text { Urology ward } \\
\text { (106 cultures) } \\
\text { No. }(\%) \text { positive }\end{array}$ \\
\hline $\begin{array}{l}\text { Klebsiella-Aerobacter } \\
\text { Intermediate coliforms } \\
\text { Herellea } \\
\text { Pseudomonas } \\
\text { Proteus species } \\
\text { Miscellaneous gram-negatives* }\end{array}$ & $\begin{aligned} 42 & (41.6 \%) \\
25 & (24.8 \%) \\
20 & (19.8 \%) \\
6 & (5.9 \%) \\
5 & (5.0 \%) \\
20 & (19.8 \%)\end{aligned}$ & $\begin{array}{l}25(23.8 \%) \\
20(19.0 \%) \\
13(12.4 \%) \\
11(10.5 \%) \\
6(5.7 \%) \\
18(17.1 \%)\end{array}$ & $\begin{array}{r}24(22.6 \%) \\
10(9.4 \%) \\
6(5.7 \%) \\
6(5.7 \%) \\
9(8.5 \%) \\
12(11.3 \%)\end{array}$ \\
\hline $\begin{array}{l}E . \text { coli } 04,06,075 \\
E \text {. coli (all other groups) } \\
\text { No growth }\end{array}$ & $\begin{array}{c}\text { (205 cultures) } \\
5(2.4 \%) \\
30(14.6 \%) \\
36(17.8 \%)\end{array}$ & $\begin{array}{c}\text { (208 cultures) } \\
7(3.4 \%) \\
21(10.0 \%) \\
65(31.4 \%)\end{array}$ & $\begin{array}{c}\text { (106 cultures) } \\
6(5.7 \%) \\
11(10.4 \%) \\
44(41.5 \%)\end{array}$ \\
\hline
\end{tabular}

* Includes equal numbers of Achromabacter, Alcaligenes, and Paracolon.

$2,6,12$, or 24 hours. The plates were distributed in 35 rooms, and only 17 gram-negative colonies were cultured. Klebsiella and Flavobacterium were found in five instances each, followed by intermediate coliforms, which were cultured four times. Only three colonies of $E$. coli were isolated from three separate plates. Two colonies were 06 , and one was 04 .

Another potential reservoir of $E$. coli 04,06 , and 075 investigated within the hospital was the stool flora of hospital personnel. Rectal swabs were obtained from 52 medical ward personnel whose duties included daily, intimate contact with patients. Two of the specimens contained no E. coli. Twenty of the remaining 50 persons $(40 \%)$ were carriers of 04,06 , and 075 . Carriers of these strains were equally distributed among personnel from both the North and South medical units. Although the carrier rate among personnel represents an increase over the $28 \%$ stool carrier rate found in patients at the time of admission, the difference is not statistically significant.

Influence of $O$ antibody titer in the host on susceptibility to colonization by E. coli 04, 06, and
075. Serum $\mathrm{O}$ antibody titers against homologous intestinal $E$. coli were performed in 111 patients who were intestinal carriers of $E$. coli 04,06 , or 075 upon admission to the hospital and in 273 in whom these organisms were not present in the stool. The results are summarized in Table V. As a rule, intestinal carriers of each of the three prevalent $O$ groups showed higher titers against the homologous intestinal isolate than were present in noncarriers. However, the differences were not significant, and no deficit in group-specific serum antibody was demonstrated in patients who were community carriers of these strains. Groupspecific $\mathrm{O}$ antibody titers at the time of admission to the hospital were measured in the 33 patients who acquired E. coli 04, 06, and 075 in the hospital and were contrasted with the mean titers of 103 patients who did not acquire these $\mathrm{O}$ groups ( $\mathrm{Ta}$ ble VI). Again, no deficiency in host $\mathrm{O}$ antibody could be demonstrated to explain the propensity of hospitalized patients to become colonized with $E$. coli 04, 06, and 075 .

Incidence of hospital-acquired urinary tract infection. Of the initial group of 425 patients, 7

TABLE V

Serum levels of specific $O$ antibody in community carriers of serogroups 4, 6, and 75

\begin{tabular}{|c|c|c|c|c|c|c|}
\hline \multirow[b]{2}{*}{ Stool flora } & \multicolumn{2}{|c|}{ Anti-04 antibody } & \multicolumn{2}{|c|}{ Anti-06 antibody } & \multicolumn{2}{|c|}{ Anti-075 antibody } \\
\hline & $\begin{array}{l}\text { Carriers of } \\
E . \text { coli } 04\end{array}$ & $\begin{array}{c}\text { Noncarriers } \\
\text { of } E \text {. coli } \\
04,06 \text {, or } 075\end{array}$ & $\begin{array}{l}\text { Carriers of } \\
E . \text { coli } 06\end{array}$ & $\begin{array}{c}\text { Noncarriers } \\
\text { of } E \text {. coli } \\
04,06 \text {, or } 075\end{array}$ & $\begin{array}{l}\text { Carriers of } \\
\text { E. coli } 075\end{array}$ & $\begin{array}{c}\text { Noncarriers } \\
\text { of } E \text {. coli } \\
04,06 \text {, or } 075\end{array}$ \\
\hline Number of patients & 18 & 273 & 64 & 73 & 29 & 273 \\
\hline Antibody titer* & 7.11 & 6.65 & 8.42 & 7.66 & 6.00 & 5.81 \\
\hline
\end{tabular}

* Expressed as mean of twofold tube dilutions. 
TABLE VI

Relationship between group-specific antibody and susceptibility to intestinal colonization with homologous serogroups

\begin{tabular}{|c|c|c|c|c|c|c|}
\hline \multirow[b]{2}{*}{ Stool flora } & \multicolumn{2}{|c|}{ Anti-04 antibody } & \multicolumn{2}{|c|}{ Anti-06 antibody } & \multicolumn{2}{|c|}{ Anti-075 antibody } \\
\hline & $\begin{array}{l}\text { "Con- } \\
\text { vertors" } \\
\text { to } \\
\text { E. coli } \\
04\end{array}$ & $\begin{array}{c}\text { Noncarriers } \\
\text { and non- } \\
\text { convertors } \\
\text { to } 04,06,075\end{array}$ & $\begin{array}{l}\text { "Conver- } \\
\text { tors" to } \\
\text { E. coli } 06\end{array}$ & $\begin{array}{l}\text { Noncarriers } \\
\text { and non- } \\
\text { convertors } \\
\text { to } 04,06,075\end{array}$ & $\begin{array}{c}\text { "Conver- } \\
\text { tors" to } \\
\text { E. coli } 075\end{array}$ & $\begin{array}{l}\text { Noncarriers } \\
\text { and non- } \\
\text { convertors } \\
\text { to } 04,06,075\end{array}$ \\
\hline Number of patients & 9 & 105 & 13 & 103 & 11 & 103 \\
\hline Antibody titer* & 7.0 & 6.57 & 7.69 & 7.62 & 5.82 & 5.66 \\
\hline
\end{tabular}

* Expressed as mean of twofold tube dilutions.

were admitted with the diagnosis of suspected urinary tract infection, which was confirmed by culture. An additional 41 patients $(9.7 \%)$ had asymptomatic bacteriuria on admission on the basis of two consecutive cultures showing $10^{5} \mathrm{gram}$ negative organisms per $\mathrm{ml}$ urine. Follow-up cultures, obtained at the time of discharge from the hospital, were available from 175 patients whose admission urine cultures were sterile. Of this group, 142 did not have any genitourinary tract instrumentation, catheterization, or manipulation during their hospital stay. Thirty-three patients had indwelling Foley catheters at some time during hospitalization. None of the 142 patients who were not treated with instruments developed a urinary tract infection, whereas 14 of the 33 who were subjected to urinary manipulation had significant bacteriuria. In addition to giving urines for cultures at the time of discharge, all patients were surveyed for the development of symptomatic urinary tract infection by daily questioning by house officers. This method of surveillance assured that clinically apparent infections that were successfully treated would be included as "hospital-acquired," even though negative cultures were present at time of discharge. Despite the high rate of acquisition of $E$. coli serogroups 4,6 , and 75 in the stools of hospitalized patients, only those patients undergoing urinary tract manipulation developed bacteriuria. Of 14 infections which developed in the hospital, 6 were due to $E$. coli. Two patients had 06, one 04, and three developed urinary tract infections with miscellaneous serogroups.

\section{Discussion}

$E$. coli is one of the most common organisms causing gram-negative hospital-acquired infection
(9-11). It is clear from previous studies that strains in a few serological groups, $E$. coli 04, 06, and 075 are responsible for the majority of coliform infections $(1-5,12,13)$. The present study deals primarily with asymptomatic fecal carriers rather than patients with overt infection. However, among the few infections uncovered, $E$. coli 04,06 , and 075 were again significant pathogens. Although these are not the strains responsible for infantile diarrhea, intestinal colonization by $E$. coli 04,06 , and 075 appears to antedate urinary tract infection both in the hospital and in domiciliary patients $(4,5)$. To obtain better understanding of this problem and, hopefully, to ultimately control it, we must define the reservoirs, mode of cross infection, and factors affecting the virulence of these organisms.

Hospitalized patients, in particular, show an increased susceptibility to intestinal colonization by $E$. coli serogroups 4,6 , and 75 . In the current study, $46 \%$ of the patients hospitalized 3 weeks or longer had become colonized by 04,06 , or 075 at the time of discharge, although only $28 \%$ were carriers of these $E$. coli in the stool on admission to the hospital. This corroborates previous data collected from this laboratory which demonstrated an unusually high incidence of intestinal colonization with these specific serogroups in hospitalized patients (4). Although other strains of $E$. coli were carried in the stool as frequently as 04,06 , and 075 , only these organisms caused a significant number of urinary tract infections among patients subjected to prostatectomy. Our work as well as previous studies, emphasizes that colonization of the stool by $E$. coli alone does not result in infection of the urinary tract in patients in the hospital. The sine qua non for nosocomial uri- 
nary tract infections is urologic instrumentation, catheterization, and manipulation $(10,14)$. However, when infection takes place in patients who have been treated with instruments, it is more likely to be due to 04,06 , and 075 than other coliforms.

The high rate of colonization with certain coliforms was present only during the winter months of December, January, and February, and admission and discharge stool carrier rates for $E$. coli 04, 06, and 075 were no different in March and April. This seasonal variation in the prevalence of specific $E$. coli was unexplained and may be a chance phenomenon related, perhaps, to the relatively small number of patients studied. The over-all number of admissions, average duration of hospitalization, and use of antimicrobials were similar throughout the 5-month period of surveillance. This pattern of winter predominance may be similar to the recently reported seasonal variations in nosocomial staphylococcal wound infections (15). An expanded year-long surveillance program is in progress to define the seasonal variations in intestinal colonization and its relationship to extraintestinal infection more precisely.

The exact sources of contamination and mode of transmission of specific coliforms within the hospital remain unclear. The environmental reservoirs of $E$. coli 04,06 , and 075 were sparse, and isolation of these organisms from inanimate objects was so infrequent that it is highly unlikely that these objects served as important foci of contamination. Furthermore, although the stool carrier rate of 04,06 , and 075 among hospital personnel was relatively high, it was not significantly different from that of a community population comparable in age.

The failure to identify significant hospital reservoirs of specific $E$. coli suggests that increased colonization by serogroups 04,06 , and 075 is due to an emergence of these strains from the patient's endogenous stool flora. That is, $E$. coli $O$ groups 4,6 , or 75 could be present in very small numbers at the time of admission, and because only 10 colonies are identified in each rectal swab, they would not be isolated (6). Subsequently, alteration of the intestinal flora by antibiotics, host disease, and other as yet unidentified factors permits emergence of these strains as predominant components of the fecal flora and enhances the ease with which they can be cultured. It is also conceivable that certain changes in the stool, such as $\mathrm{pH}$, solute, and total water content may prove to be important in the recovery of certain coliforms (16). Certainly, multiple or broad spectrum antimicrobial therapy appears to be a significant factor in the acquisition of 04,06 , and 075 within the hospital. These strains did not appear to become resistant to antimicrobial agents, at least when the disc technique was employed. It is possible, of course, that more subtle variations in antimicrobial susceptibility, which would not be apparent with the disc technique, occurred. It seems more plausible, however, to suggest that antibiotics and other factors altered some other components of the fecal flora permitting emergence of $E$. coli 04,06 , and 075 . Although multiple stool cultures were not obtained over a short period of time, other investigators have made serial observations on the stool carriage of specific E. coli. Wallick and Stuart (17) and Sears and co-workers $(18,19)$ demonstrated remarkable stability in the $E$. coli serogroups isolated from a single individual. In one study, stools of eight normal subjects were sampled for periods from 10 months to 4 years, and the intestinal $E$. coli flora was divided into "resident" and "transient" organisms. Resident strains were defined as organisms that were cultured consistently for 6 months or longer, whereas transient strains consisted of serogroups that were isolated only sporadically and rarely persisted longer than 1 to 2 weeks. The resident flora was unchanged during bouts of acute diarrhea, feeding of exogenous $E$. coli, and in one patient, administration of an antimicrobial. Serogroups 4, 6, and 75 might be considered, then, the transient flora of the hospital, which colonizes subjects during hospitalization. Usually, these organisms are lost relatively quickly when the patient returns to the community (4).

There is no question that $E$. coli 04,06 , and 075 are the most common strains causing urinary tract infection not only in the hospital but also in the community (12). However, it is not known whether intestinal 04, 06, and 075 cultured from patients in the community with acute uncomplicated urinary tract infections represent transient or resident flora. Since $90 \%$ of patients acquiring $E$. coli urinary tract infections outside the hospital have been shown to be stool carriers 
of the urinary pathogens at the time of recognition of symptomatic illness, a clear separation of resident and transient flora in the community would be an important advance in the epidemiology of these infections. Although it is conceivable that the stool flora merely reflects contamination by infected urine and that the high stool carrier rate is a function of antecedent infection, it is more plausible that the infection of the genitourinary tract is caused by $E$. coli in the bowel. In addition, in the present study only the somatic $(\mathrm{O})$ antigens of $E$. coli were determined. It is possible that further characterization of these strains by means of flagellar $(\mathrm{H})$ and capsular $(\mathrm{K})$ antigens will add to our knowledge of the epidemiology of these infections.

Other than appearing to have enhanced epidemiologic virulence, which is defined as an increased propensity of these strains to colonize the bowel and to produce infection, the factors responsible for the behavior of $E$. coli 04,06 , and 075 are poorly understood. Sjöstedt tested the relative virulence of eight different $O$ groups of $E$. coli by measuring their median lethal dose $\left(\mathrm{LD}_{50}\right)$ in mice, their ability to produce necrosis of tissue, and their resistance to phagocytosis and to the bactericidal action of serum (20). Serogroups 4 and 6 showed some tendency to increased virulence, whereas other $\mathrm{O}$ groups were less active. Kimball, Garcia, and Petersdorf also found that 04, 06, and 075 were more resistant to serum than $E$. coli in other serogroups (21). However, these investigators were unable to demonstrate any differences in the abilities of various serogroups of E. coli to cause experimental pyelonephritis (22).

The possibility remains that a deficiency within the host rather than intrinsic virulence of the microorganism is responsible for the high rate of infection with certain strains. Recently, groupspecific $O$ antibody to all 145 known serogroups of $E$. coli has been demonstrated in the sera of normal adults. It is felt that this antibody arises in response to the antigenic mass in the colon (23, 24). However, whether $\mathrm{O}$ antibody exerts protective action in $E$. coli infections has been controversial. Although Sanford, Hunter, and Souda (25) have been able to induce immunity to experimental $E$. coli pyelonephritis by means of both active and passive immunization, others have cast doubt on the significance of these antibodies be- cause of the persistence or recurrence of urinary tract infections with the same serologic strains in patients with high homologous antibody titers (26-28). In the present study, antibody titers obtained on admission from the 33 patients who converted to intestinal carriage of $E$. coli 04,06 , or 075 were approximately equal to those found in hospitalized patients not acquiring these strains. Likewise, community carriers of these strains, as well as patients in the hospital who developed urinary tract infections, had comparable titers of antibody. These results are in agreement with those of Robinet (29), who found no relation between serum $\mathrm{O}$ antibody titers and susceptibility to colonization by homologous $\mathrm{E}$. coli. However, it is possible that serum antibody does have some protective role in man against recurrent urinary tract infection, which is difficult to ascertain because of pre-existent titers (30).

Finally, a possible mechanism for the excessive frequency of infection by specific serological strains of $E$. coli is the resistance of these strains (31-33) to colicine. Recently, studies on colicine production of $E$. coli have demonstrated that the resident flora is more frequently productive of these substances than are transient coliforms (32). Furthermore, it has also been shown that $O$ groups 4,6 , and 75 may be relatively more resistant to colicine than other serogroups (33). Further work relating colicine production and resistance to the ability of $E$. coli to colonize the gut is indicated.

\section{Acknowledgments}

We wish to acknowledge the technical assistance of Miss Christine Hauff and Mrs. Caroline Bullinger.

\section{References}

1. Turck, M., M. R. Fournier, and R. G. Petersdorf. Laboratory and clinical studies of Escherichia coli infections. Antimicrob. Agents Chemother. 1961, 113.

2. Turck, M., and R. G. Petersdorf. The epidemiology of non-enteric Escherichia coli infections: prevalence of serological groups. J. clin. Invest. 1962, 41, 1760.

3. Rantz, L. A. Serological grouping of Escherichia coli. Study in urinary tract infection. Arch. intern. Med. 1962, 109, 37.

4. Kennedy, R. P., J. J. Plorde, and R. G. Petersdorf. Studies on the epidemiology of Escherichia coli infections. IV. Evidence for a nosocomial flora. J. clin. Invest. 1965, 44, 193. 
5. Winterbauer, R. H., M. Turck, and R. G. Petersdorf. Further evidence for epidemiologic virulence of Escherichia coli. Antimicrob. Agents Chemother. 1965, 71, 1966.

6. Vosti, K. L., A. S. Monto, and L. A. Rantz. The importance of sample size in studies based upon the serologic classification of Escherichia coli. Proc. Soc. exp. Biol. (N. Y.) 1962, 111, 201.

7. Turck, M., R. I. Lindemeyer, and R. G. Petersdorf. Comparison of single-disc and tube-dilution techniques in determining antibiotic sensitivities of gram-negative pathogens. Ann. intern. Med. 1963, 58, 56.

8. Neter, E., L. F. Bertram, D. A. Zak, M. R. Murdock, and C. E. Arbesman. Studies on hemagglutination and hemolysis by Escherichia coli antisera. J. exp. Med. 1952, 96, 1.

9. Spittel, J. A., Jr., W. J. Martin, and D. R. Nichols. Bacteremia owing to gram-negative bacilli: experiences in the treatment of 137 patients in a 15year period. Ann. intern. Med. 1956, 44, 302.

10. Grossberg, S. E., R. G. Petersdorf, J. A. Curtin, and I. L. Bennett, Jr. Factors influencing the species and antimicrobial resistance of urinary pathogens. Amer. J. Med. 1962, 32, 44.

11. Weil, M. H., H. Shubin, and M. Biddle. Shock caused by gram-negative microorganisms: analysis of 169 cases. Ann. intern. Med. 1964, 60, 384.

12. Kunin, C. M., and N. E. Halmagyi. Urinary-tract infections in schoolchildren. II. Characterization of invading organisms. New Engl. J. Med. 1962, 266, 1297.

13. Jackson, G. G., J. A. Arana, B. R. Anderson, H. C. Grieble, and W. R. McCabe. Profiles of pyelonephritis. Arch. intern. Med. 1962, 110, 633.

14. Kaitz, A. L., and E. J. Williams. Bacteriuria and urinary-tract infections in hospitalized patients. New Engl. J. Med. 1960, 262, 425.

15. Thornton, G. F., F. R. Fekety, and L. E. Cluff. Studies of the epidemiology of staphylococcal infection. VIII : Seasonal variation. New Engl. J. Med. 1964, 271, 1333.

16. Donaldson, R. M., Jr. Normal bacterial populations of intestine and their relation to intestinal function. New Engl. J. Med. 1964, 270, 983, 994, and 1050.

17. Wallick, H., and C. A. Stuart. Antigenic relationships of Escherichia coli isolated from one individual. J. Bact. 1943, 45, 121.

18. Sears, H. J., I. Brownlee, and J. K. Uchiyama. Persistence of individual strains of Escherichia coli in the intestinal tract of man. J. Bact. 1950, 59, 293.

19. Sears, H. J., and I. Brownlee. Further observations on the persistence of individual strains of Escherchia coli in the intestinal tract of man. J. Bact. 1952, 63, 47.
20. Sjöstedt, S. Pathogenicity of certain serological types of $B$. coli: their mouse toxicity, hemolytic power, capacity for skin necrosis and resistance to phagocytosis and bactericidal faculties of human blood. Acta. path. microbiol. scand. 1946, 63 (suppl.), 1.

21. Kimball, H., M. Garcia, and R. G. Petersdorf. The epidemiology of nonenteric Escherichia coli infections. II. Relationship of prevalence of $E$. coli in urinary infections to the bactericidal effect of human serum. J. Lab. clin. Med. 1964, 63, 901.

22. Kimball, H., M. Turck, and R. G. Petersdorf. The epidemiology of nonenteric Escherichia coli infections. III. Relationship of $E$. coli antigens to experimental pyelonephritis. J. Lab. clin. Med. 1964, 63, 907.

23. Kunin, C. M. Antibody distribution against nonenteropathic E. coli. Arch. intern. Med. 1962, 110, 676.

24. Austen, K. F., and Z. A. Cohn. Contribution of serum and cellular factors in host defense reactions. New Engl. J. Med. 1963, 268, 933, 994, and 1056.

25. Sanford, J. P., B. W. Hunter, and L. L. Souda. Role of immunity in pathogenesis of experimental hematogenous pyelonephritis. J. exp. Med. 1962, $115,383$.

26. Williamson, J., H. Brainerd, M. Scaparone, and S. P. Chueh. Antibacterial antibodies in coliform urinary tract infections. Arch. intern. Med. 1964, 114, 222.

27. Vosti, K. L., L. M. Goldberg, A. S. Monto, and L. A. Rantz. Host-parasite interaction in patients with infections due to Escherichia coli: the serogrouping of $E$. coli from intestinal and extraintestinal sources. J. clin. Invest. 1964, 43, 2377.

28. Carter, M. J., and N. H. Ehrenkranz. Immunologic studies in urinary tract infections. II. Correlation of hemagglutinin response with bacteriuria following catheterization. J. Lab. clin. Med. 1966, 67, 13.

29. Robinet, H. G. Relationship of host antibody to fluctuations of Escherichia coli serotypes in the human intestine. J. Bact. 1962, 84, 896.

30. Kunin, C. M. Asymptomatic bacteriuria. Ann. Rev. Med. 1966, 17, 383.

31. Papavassiliou, J. Lysogeny and colicinogeny in Escherichia coli. J. gen. Microbiol. 1962, 25, 409.

32. Branche, W. C., Jr., V. M. Young, H. G. Robinet, and E. O. Massey. Effect of colicine production on Escherichia coli in normal human intestine. Proc. Soc. exp. Biol. (N. Y.) 1963, 114, 198.

33. Vosti, K. L. Relationship of colicine production and sensitivity to prevalence of certain serogroups of Escherichia coli. Clin. Res. 1966, 14, 174. 